\title{
Between Religion and State
}

\section{The Concept of Law in Lutheran Protestantism}

\author{
Friedemann Barniske | ORCID: 0000-0002-0256-8308 \\ Research Assistant at the Chair of Systematic Theology/Lecturer \\ in Systematic Theology, Augustana-Hochschule Neuendettelsau, \\ Neuendettelsau, Germany \\ Friedemann.barniske@augustana.de
}

\begin{abstract}
On the basis of Martin Luther's theologia crucis in the Heidelberg Disputation (1518), the Lutheran concept of law in the 2oth Century is examined. Luther's distinction of religious and civil dimension of law with its religious restriction to a convicting function regarding the sin is received in the Luther-Renaissance of the 1920 and 1930s. The sample of Emanuel Hirsch (1888-1972) gives insight into the deeply ambivalent character of the Lutheran concept of law before World War II which combined a profound theory of Christian subjectivity with a theory of state promoting German nationalism in opposition to western democracy. The moderate theology of Wolfgang Trillhaas (1903-1995) reflecting the experience of the Nazi-Regime de-potentializes the Lutheran prejudice against the law in order to achieve new democratic perspectives on the notion of law in dogmatics and ethics. Thus, an affirmative position is established despite a remaining ambivalence in contemporary Lutheran Protestantism.
\end{abstract}

\section{Keywords}

law and gospel - state - religion - revelation - theologia crucis 


\section{Introduction}

"The essence of the church is spiritual; the essence of justice is worldly. The nature of canon law is at odds with the nature of the church."1 At the end of the 19th century, Rudolph Sohm (1841-1917), the famous Lutheran legal scholar, radically excluded the idea of law from the ideational sphere of church which he understood as the spiritual community in Christ, as realized among early Christians and in Luther's ecclesiological doctrine. ${ }^{2}$ Luther had not only distinguished between visible and invisible church - an unpleasant idea to a lot of conservative Lutheran theologians of the last 5 oo years - in order to accentuate the liberating potential of Christian community in faith; but he also established a new understanding of law in general in his theology. In fact, he ascribed a new role to the concept of law which has had a great and lasting impact on the Lutheran attitude towards the legal sphere. Therefore, we will take a closer look at Martin Luther's own concept within the framework of the idea of divine self-revelation as expressed in his theology of the cross, in order to assess the reformational foundation to the Lutheran notion of law (ch. 2). Then, an examination of the theological reception of Luther's conception in both the first and second half of the 2oth century will follow, which shall provide us with the characteristic course of the fate of law. In this context, both systematic spheres of the Lutheran concept of law will be discussed - the distinction of law and gospel as well as the field of legal right and the theory of state.

For that purpose, we will reconstruct relevant ideas of two characteristic Lutheran theologians: the radical Emanuel Hirsch (1888-1972), a brilliant scholar of protestant freedom, abysmal thinker of German nationalism and devoted Nazi at the same time (ch. 3 and 4); and Wolfgang Trillhaas (19031995), a moderate Southern German Lutheran with his modern approach mediating between Lutheran thought and democracy, thus cracking up the traditional Lutheran view on law both in the religious and the legal sphere (ch. 5). Eventually, we will conclude by looking at the role of the concept of law in contemporary Lutheran Protestantism in Germany and the divergent tendencies related to it (ch. 6).

1 Sohm, Kirchenrecht, p. x: „Das Wesen der Kirche ist geistlich, das Wesen des Rechts ist weltlich. Das Wesen des Kirchenrechts steht mit dem Wesen der Kirche im Widerspruch.“

2 See Thier, Rudolph Sohm. 
Given the opportunity to explain his religious and theological convictions within the setting of an academic disputation, Martin Luther (1483-1546) came to Heidelberg in April 1518. Besides articulating his ground-breaking thoughts on the essence of Christian faith and its proper self-reflection in theology, he also touched upon the notion of religious law and its function related to true evangelic faith. The latter one of course being based on the idea of divine grace which is granted unconditionally to all who believe and trust in Jesus Christ, the crucified. Therefore, the religious or theological understanding of law - as we will continue to refer to in addition to the political one - established in the Heidelberg Disputation (1518) is closely connected to Luther's complex notion of Christian revelation. In the third major part of the Latin text (theses XIXXXIV) he is unfolding his idea of a theologia crucis which is summed up in the word: "CRUX sola est nostra theologia." ${ }^{3}$ Human reason, which is necessarily finite, is in itself unable to comprehend the essence of divine nature. Luther clearly rejects any kind of theologia gloriae that would attempt to speculate on God's very own characteristics such as omnipresence, wisdom, eternity etc. neglecting the boundaries of human knowledge. One might say God, in his glory cannot be understood as an object of our limited reasoning. Instead, the concept of a theology of the cross is developed in order to re-establish the crucified Lord as the core of Christian belief and understanding of God himself. Similar to the critical and transcendental philosophies of the Lutherans Immanuel Kant (1724-1804) and Johann Gottlieb Fichte (1762-1814), that concept is structured by antithetic or even antinomic thoughts. ${ }^{4}$ Here, the famous systematic distinction of Deus absconditus and Deus revelatus is utilized in order to express the different aspects of the divine for the Christian. Jesus Christ and his cross are exposed as the exclusive spot of divine revelation. ${ }^{5}$ Yet, this revelation itself is by no means revealing the glory of God as such. In fact, the whole idea of revelation, which Luther elaborates in his theses, actually turns the epistemic aspect of faith on its head. "Non ille digne Theologus dicitur, qui invisibilia Dei, per ea, quae facta sunt, intellecta conspicit." ${ }^{6}$ Those

3 Martin Luther on Ps 5,12; Luther, Operationes in Psalmos, in: Luthers Werke (wA 5), p. 176,32.

4 Concerning the connection of Lutheran thought and Classical German Philosophy in 2oth Century Protestant Theology see Barniske, Persönlichkeitsreligion.

5 See Barth, Die Dialektik des Offenbarungsgedankens.

6 Luther, Disputatio Heidelbergae habita, 52/wA 1, p. 361; Martin Luther, Heidelberg Disputation, p. 52: "That person does not deserve to be called a theologian who looks upon the invisible things of God as though they were clearly perceptible in those things which have actually happened (Rom. 1:20)." 
foolish attempts to reach out for the divine mystery itself do not reveal anything but the hybris of their producer's finite reasoning on God's properties. Luther's attack on the theologia gloriae is inspired by St. Paul calling the people of the world's wisdom fools (Rom 1:22). In contrast to their speculative efforts in exploring the invisible aspects or essence of God (invisibilia Dei), the true Christian theologian has to focus on the visible side of the divine. Actual theology recognizes the aspect of God which became accessible through the incarnation of the divine word (John 1:1) Jesus Christ who lived and participated in human life and nature, thus submitting himself to the law of creation and sin. It is not the speculative theologian in the scholastic sense of the word who is gaining any knowledge of God's nature or will, but the one beholding the unique place of God's revelation in Christ, which is - according to Martin Luther - the cross. "Ille [...] qui visibilia et posteriora Dei, per passiones et crucem conspecta intelligit."7 Suffering becomes the signature of the divine and the visible shame and humiliation of the logos incarnatus becomes the sign of revelation in the Christian sense. Humanity and weakness are the characteristics of the Deus revelatus in Christ, whereas power, glory and wisdom etc. belong to the divine aspects hidden in the Deus absconditus. Thus, the true nature of God is definitely covered under the ugliness of the cross. According to Luther, the cross of Golgotha marks the divine decision to be revealed in the suffering of this human being Jesus of Nazareth, who is exposed as the human par excellence, and not through the world's wisdom. "[V]oluit [...] Deus ex passionibus cognosci et reprobare illam sapientiam invisibilium, per sapientiam visibilium", 8 which is the cross. This way, the concept of revelation is sustainably turned around, recognizing the hidden aspects of the divine, yet acknowledging the idea of revelation sub contrario modo. The glory of God is hidden beneath its opposite - the cross of Jesus Christ. "Ita, ut nulli iam satis sit ac prosit, qui cognoscit Deum in gloria et maiestate, nisi cognoscat eundem in humilitate et ignominia crucis. Sic perdit spientiam sapientiam etc. [I Cor 1:19] sicut Isaias dicit: Vere absconditus tu es Deus [Isa 45:15]." Martin Luther revo-

7 Luther, Disputatio Heidelbergae habita, 52/wA 1, p. 362; Martin Luther, Heidelberg Disputation, p. 52: "He deserves to be called a theologian, however, who comprehends the visible and manifest things of God seen through suffering and the cross."

8 Luther, Disputatio Heidelbergae habita, 52/WA 1, p. 362; Martin Luther, Heidelberg Disputation, p. 52: "God wished [...] to be recognized in suffering, and to condemn wisdom concerning invisible things by means of wisdom concerning visible things."

9 Luther, Disputatio Heidelbergae habita, 52/WA 1, p. 362; Martin Luther, Heidelberg Disputation, p. $5^{2}$ et al.: "Now it is not sufficient for anyone, and it does him no good to recognize God in his glory and majesty, unless he recognizes him in humility and shame of the cross. Thus God destroys the wisdom of the wise, as Isa. (45:15) says, "Truly, thou art a God who hidest thyself." 
lutionizes the notion of revelation as well as the concept of Christian theology altogether. His theological inversion of revelation as sub contrario - glory hidden behind its opposite: shame - becomes the core of a new understanding which emphasizes the significance of the cross. It marks the epistemic condition for all theological thought: "Ergo in Christo crucifixo est vera Theologia et cognitio Dei. Et Ioh. 10. Nemo venit ad Patrem, nisi per me. [...] Theologus gloriae dicit, Malum bonum, et bonum malum, Theologus crucis dicit, id quod res est."10

Both aspects of revelation and the new understanding of Christian theology as such have a significant impact on the concept of law. The idea of the Deus absconditus revealing himself in the passion of Christ is reflected in another theological distinction which is equally important to Luther's religious thought. Elaborating the special character of God's action in this world, Luther is reasoning on its aspect of negativity - to use a Hegelian term of interpretation. In his fourth thesis, the structure of the revelatio sub contrario modo is already engaged in order to comprehend the contradictory dimension of the divine. "Opera Dei, ut semper sint deformia, malaque videantur, vere tamen sunt merita immortalia."11 God's action with his creatures appears ambiguous or even as contradictory to human understanding. Yet, this is the way in which the divine is revealed according to the biblical testimony. As the hidden God reveals himself exclusively in the crucified son of man, the religious belief experiences the divine action along the very same epistemic pattern. In Heidelberg, Martin Luther exposed this same pattern among the different forms also with regard to God's action drawing on a string of rather obscure verses from the Bible. But Luther's skilled Augustinian exegetical mind establishes a hermeneutical key identifying the ambivalence of our comprehension of the divine as a necessary element of God's appearance. His action is of course ambiguous - but only to our human comprehension. "Dominus mortificat et vivificat, deducit ad inferos et reducit."12 [1 Sam 2:6]. The mortifying as well as the vivifying aspect of divine action towards his creature is eventually interpreted alongside a certain

10 Luther, Disputatio Heidelbergae habita, 52/WA 1, p. 362; Martin Luther, Heidelberg Disputation, p. 53: "For this reason true theology and recognition of God are in the crucified Christ, as it is also stated in John 10 (John 14:6): 'No one comes to the Father, but by me.' [...] A theologian of glory calls evil good and good evil. A theologian of the cross calls the thing what it actually is."

11 Luther, Disputatio Heidelbergae habita, 38/wA 1, p. 356; Martin Luther, Heidelberg Disputation, p. 44: "Although the works of God always seem unattractive and appear evil, they are nevertheless really eternal merits."

12 Luther, Disputatio Heidelbergae habita, 38/wA 1, p. 356; See Martin Luther, Heidelberg Disputation, p. 44: "The Lord kills and brings to life; he brings down to Sheol and raises up." [I Sam 2:6]. 
verse from the book of Isaiah: "Et hoc est, quod Esaias cap. 28 vocat, opus alienum Dei, ut operetur opus suum [Isa 28:21] (id est, nos humiliat in nobis, desperantes faciens, ut exaltet in sua misericordia, sperantes faciens)". ${ }^{13}$ The antithesis of opus alienum and opus suum or opus proprium marks Luther's characteristic comprehension of religious experience. The finite world cannot be understood but in dialectical terms - even more so the divine source it is sprung from. God's action appears exclusively as a movement according to the dialectical structure of the cross. He instantiates his alien work in order to establish his proper work, humiliating in order to exalt us, mortifying in order to revive us. Thus, Luther establishes his own dialectical hermeneutics, which he employs on all phenomena he encounters throughout his religious and political life. Of course, he does not maintain the difference of opus proprium and opus alienum throughout his theological work, but famously inaugurates a special theological conceptualization. The dialectics described is exposed with reference to St. Paul's interpretation of the religious law. God is revealing himself and his glory underneath its opposite, i.e. under the ugliness of the cross, which is in itself a resemblance of the fallen creation and the law. The latter functions as the chiffre of ambivalence as such. When Luther describes God's action as dialectics of alien and proper work, he easily transposes this notion into the term of law. "Hoc sic intelligitur, quod Dominus humiliat et perterrefacit nos Lege et conspectu peccatorum nostrorum". ${ }^{14}$ The Lord is using the law in order to humiliate us, engaging his opus alienum to prepare us for his opus proprium - to exalt us in his grace. Thus, Martin Luther establishes his religious and theological concept of law and gospel, which becomes the magical word, not only to the interpretation of the Holy Bible but to decipher the overall reality of God, the world and human conscience altogether. All opaque aspects of religious and political experience come to light along the line of the dialectical reading of law and gospel (or grace) in accordance to the nature of God's action towards human creatures. "Lex humiliat, gratia exaltat. Lex timorem et iram, gratia spem et misericordiam operatur."15 Luther postulates

13 Luther, Disputatio Heidelbergae habita, 38/wA 1, p. 357; Martin Luther, Heidelberg Disputation, p. 44: "And that it is which Isa. 28 (:21) calls the alien work of God that he may do his work (that is, he humbles us thoroughly, making us despair, so that he may exalt us in his mercy, giving us hope)".

14 Luther, Disputatio Heidelbergae habita, 38/wA 1, p. 356; Martin Luther, Heidelberg Disputation, p. 44: "This is understood to mean that the Lord humbles and frightens us by means of the law and the sight of our sins".

15 Luther, Disputatio Heidelbergae habita, 48-50/wA 1, p. 361; Martin Luther, Heidelberg Disputation, p. 51: "The law humbles, grace exalts. The law effects fear and wrath, grace effects hope and mercy." 
a specific religious meaning of law by ascribing the epistemic role of teaching us our sin. The law prepares the sinner for divine grace in Christ. "Per Legem enim cognitio peccati [Rom 3:20], per cognitionem autem peccati humilitas, per humilitatem gratia acquiritur."16 Thus, the law indicating human sin bears the signature of God's opus alienum aiming at his grace. "Sic opus alienum Dei inducit tandem opus eius proprium, dum facit peccatorem, ut iustum faciat."17

Martin Luther's religious and ethical thought was largely re-discovered during the first decades of the 2oth century due to the new Weimar edition of his works. In the process of this re-discovery, new sources came to light such as his famous lectures on St. Paul's letters to the Romans and Galatians. Thus, the religious idea of freedom from the law once more was focussed on by Protestant theologians like Karl Holl (1866-1926) who became the main figure in the so-called "Luther-Renaissance". ${ }^{18}$ In his volume on Martin Luther, he covered both sides of the Lutheran aspects to Christianity. ${ }^{19}$ On the one hand, the articles "Was verstand Luther unter Religion?"20 [What did Luther Understand by Religion?] and "Die Rechtfertigungslehre in Luthers Vorlesung über den Römerbrief mit besonderer Rücksicht auf die Frage der Heilsgewißheit"21 [The Doctrine of Justification with Particular Regard to the Idea of Salvation] extract the notion of justification in the Christian consciousness as the true core of Luther's religious understanding of faith. Justification in Christ comes to light again as the liberating experience of religious subjectivity - liberating from the troublesome and despairing pressure of God's religious law. And the individual consciousness is identified as the place where true experience of God's living word is taking place. That is why Holl concludes that Martin Luther's concept of religion could be summed up in the notion of a "religion of conscience". ${ }^{22}$ On the other hand, Holl is engaging in the political side of

16 Luther, Disputatio Heidelbergae habita, 50/wA 1, p. 361; Martin Luther, Heidelberg Disputation, p. 51: “Through the law comes knowledge of sin' (Rom. 3:20), through knowledge of sin, however, comes humility, and through humility grace is acquired."

17 Luther, Disputatio Heidelbergae habita, 50/wA 1, p. 361; Martin Luther, Heidelberg Disputation, p. 51: "Thus an action which is alien to God's nature results in a deed belonging to his very nature: he makes a person a sinner so that he may make him righteous."

18 See Assel, Der andere Aufbruch and Assel, Introduction.

19 See Holl, Gesammelte Aufsätze zur Kirchengeschichte.

20 Holl, Gesammelte Aufsätze zur Kirchengeschichte, pp. 1-9o.

21 Holl, Gesammelte Aufsätze zur Kirchengeschichte, pp. 91-130.

22 Holl, Gesammelte Aufsätze zur Kirchengeschichte, p. 30: „Gewissensreligion“. 
Luther's thought and his impact on modern protestant ethics in general. His article "Der Neubau der Sittlichkeit"23 [The Rebuilt of Ethical Life] exposes the Lutheran concept of ethical life based on the religious root of a strong idea of the unconditional will of God, which converges with the moral commitment of the Christian individual, thus gaining the personal freedom to build his ethical world in responsibility to the next. ${ }^{24}$ In this framework, complex and even divergent phenomena of human life such as Christian love and the use of bloody violence in order to maintain law and justice are synthesized within Lutheran ethics. ${ }^{25}$ Therefore, one can conclude, Holl's multi-aspect view on Martin Luther's concept of Christian faith and life enables him to combine a radically modern idea of religion with a rather conservative-Kantian picture of ethical life. While the notion of religion is based exclusively on the individual consciousness overcoming any significance of religious law at all, the relation to the unconditional and his call in Christian's conscience unfolds a concept of freedom and responsibility that is eager to uphold political institutions such as family, state and law.

Emanuel Hirsch (1888-1972) was, without a doubt, one of Holl's most talented students in Berlin in the early years of the century - from 1904-1908. He later became Professor of Church History (1921) and Systematic Theology (1936) at the University of Göttingen and became heavily engaged in the Nazi-Regime, which led to his retirement and loss of faculty rights in 1945 .

Although his explication of modern Protestantism is deeply influenced by the classical philosophy of German Idealism - Hirsch is considered the main engine of a theological Neo-Fichteanism in Germany in the 2oth century ${ }^{26}$ the Lutheran character of his religious thought is undeniable. In fact, he promoted the idea of a so-called Luther-Renaissance unlike any other of Holl's former students. And similar to the double picture of Luther's religious and ethical concept of true Christianity, Hirsch reflects on both aspects in his own historic and systematic work. Despite his very early research on the Lutheran notion of state and the two realms of God's effectiveness in the world, we will focus on Hirsch's systematic main work, the Leitfaden zur christlichen Lehre (1938), which encompasses Protestant dogmatics (see §§ 1-10o) as well as ethics (see $\S \S 101-130) .{ }^{27}$

\footnotetext{
23 Holl, Gesammelte Aufsätze zur Kirchengeschichte, pp. 131-244.

24 See Holl, Gesammelte Aufsätze zur Kirchengeschichte, p. 244.

25 See Holl, Gesammelte Aufsätze zur Kirchengeschichte, p. 242.

26 See Barth, Nachwort des Herausgebers.

27 Von Scheliha, Emanuel Hirsch als Dogmatiker gives a thorough insight to the foundations of Hirsch's dogmatics whereas Lobe, Die Prinzipien der Ethik Emanuel Hirschs deals with the Lutheran and Neo-Fichtean basis of his ethics within and beyond the Leitfaden.
} 
Starting with his reception of the Lutheran notion of law in the religious context that gives the phenomenological basis for its dogmatic reflection, we have to focus on the distinction of law and gospel within the framework of Hirsch's theory of Christian revelation. In accordance with the Lutheran tradition, he unfolds his notion of divine revelation strictly in spiritual terms which can also be read in the philosophical light of German Idealism. First of all, Christian revelation is explained in the context of a discussion of the properties of the divine word itself. "The word as revelation"28 constitutes the sphere in which the necessity arises to differentiate between several functions of the word - Jesus Christ, the Logos (John 1) - and its reception in human and Christian consciousness. In opposition to any pre-Christian concept of revelation, Hirsch believes in the word-character of the human-divine relationship which takes place in the subjective consciousness of each Christian blessed with the true faith and trust in the divine word. "According to Christian understanding, revelation is God's action towards me, which determinates myself in my own personal conscience before God, thus deciphering God for me."29 This complex structure of the "clarity of self-knowledge"30 in the light of God expresses the spiritual character of Christian revelation. This way he does not only exclude any attempt to an ontological understanding of faith, which is rather restricted to the sphere of pagan idolatry. Moreover, Hirsch gains a modern combination of the Lutheran notion of faith in its explanation by Karl Holl with the idealistic and romantic heritage of Johann Gottlieb Fichte and Søren Kierkegaard regarding the idea of self-clarity. Revelation is nowhere else to be found but at the core of human subjectivity - "heart and conscience" in Lutheran terms. ${ }^{31}$

This description of the formal systematic structure of revelation is being filled with its material ingredients which complete the picture in adding the Christian characteristics to the concept discussed. Of course, the idea of encountering God's will in the heart of a moved consciousness is built upon a

28 Hirsch, Leitfaden zur christlichen Lehre, p. 132: „Das Wort als Offenbarung“.

29 Hirsch, Leitfaden zur christlichen Lehre, p. 132 (\$ 73): „Christlich verstanden ist Offenbarung ein mich in meinem persönlichen mich Vernehmen [= Gewissen] vor Gott bestimmendes und mir darin Gott erschließendes gegenwärtiges Handeln Gottes an mir.“

$30 \quad$ Hirsch, Leitfaden zur christlichen Lehre, p. 132 (§ 73): „Durchsichtigkeit der Selbsterkenntnis".

31 In addition to Luther, Fichte and Kierkegaard, the early Hegel of the Phenomenology of Spirit plays a significant role for Hirsch's work on the topic. In his article Die Beisetzung der Romantiker in Hegels Phänomenologie [1924] he gives his original interpretation of the Hegelian notion of conscience. He describes it as the structure of self vs. self within one self which is overcome by absolute spirit, yet, rejecting this Hegelian solution. Instead, he prefers the path of Kierkegaard's existential dialectics. 
personalistic aspect brought to the picture. "Revelation can only happen in the way that a human-historical reality turns into an encounter with God in sense, heart and conscience."32 It seems as if the Christian concept of revelation is necessarily connected to the personal aspect of encountering in general. There is no possible relationship or even knowledge of the possibility of one - not to mention the realization of its deeper experience - without any interpersonal connection taking place. Yet, this interpersonal aspect of revelation is not adequately described using non-subjective and non-intersubjective terms. The condition of true encounter between religious subject and the divine itself excludes all finite and therefore potentially false religious laws of human making. For all finite attempts to declare themselves as unconditional would degrade the absolute source of revelation itself. "Any [...] enslaving under something earthly, as if it was the eternal and divine itself, would be darkening and limitation of the revelation; for the majesty of the eternal, which enlightens me, aims at giving me freedom and life in God."33 Unsurprisingly, the true and ultimate idea of revelation contradicts all laws as such which could enact a finite force within the religious sphere of the relationship between human creature and its eternal counterpart, no matter if they are concerning ethical life or religious thought. "Therefore, the ultimate revelation repeals all religious statutes as untruth, be it those for doing or those for thought." ${ }^{34}$

Regarding the further explanation of the structure of Christian revelation and its content, Hirsch exposes the material side of the encounter between God and the religious subject. This way the abstract content of the formal structure of revelation - interpersonal encounter with God in the believing heart - turns into form itself in gaining its own material aspect. The encounter with God provides the necessary form without which no relationship of finite and unconditional sphere would even be possible. Being the specific structure of the abstract structure of revelation, encountering the divine eventually becomes concrete in encountering the divine word as the personal incarnation of God himself. Thus, the interpersonal knowledge of religious subjectivity

32 Hirsch, Leitfaden zur christlichen Lehre, p. 132 (§ 73): „Geschehen kann Offenbarung nur so, daß eine menschlich-historische Wirklichkeit mir zur Begegnung mit Gott in Sinn, Herz und Gewissen wird."

33 Hirsch, Leitfaden zur christlichen Lehre, p. 132 (§ 73): „Aber jede [...] Knechtung unter ein Irdisches, als wäre es das Ewige und Göttliche selbst, wäre Verdunklung und Grenze der Offenbarung; denn die Hoheit des Ewigen, das mich darinnen erleuchtet, zielt darauf, mir Freiheit und Leben in Gott zu geben."

34 Hirsch, Leitfaden zur christlichen Lehre, p. 132 (§ 73): „Darum hebt die letzte Offenbarung alle religiösen Satzungen, es seien solche für das Tun oder solche für das Denken, als Unwahrheit auf." 
and its personalistic objective marks the true realization of Christian revelation. Nothing but spiritual religion which is unlimited by statutes or religious laws fulfils the Lutheran idea of Christian faith on the basis of intersubjective life with the eternal sphere revealing itself to and in the finite subjectivity of man. Yet, this realization of revelation as intersubjective encountering in faith depends on the personal aspect which is represented not in an abstract idea of the unconditional or God but in the personality of Jesus of Nazareth. "For Christian faith the encounter with the human being Jesus, which becomes the destiny of man's God- and Self-knowledge, is the place of what we have called the ultimate or crucial revelation." ${ }^{35}$ Revelation in the Christian sense of the word is an encounter with God, which takes place in encountering Jesus of Nazareth.

Concerning the possibility of a religious function of law, this intersubjective encounter with the person of Jesus Christ opens a new perspective insofar as the neglected meaning of religious rules is revoked in a certain sense. Although revelation is defined as the enlightening "presence of God in the conscience",36 there is a specific formal difference within Christian revelation which permits a certain role to traditional religious law as laid down in scripture. Hirsch distinguishes between "deepening and changing revelation". ${ }^{37}$ Both kinds of revelation are necessary elements of Christian faith and play their role in establishing a religious consciousness that draws on the living encounter with God in the person of Jesus Christ. The in-depth aspect of the encounter with God or the deepening side of revelation, which gives the religious law an ultimate function, provides a certain understanding of our relationship to the divine in general. It "clarifies the relationship to God, which I am already in",38 whereas the changing revelation "gives me a somehow opposite relationship to God than before". ${ }^{39}$ And again, this rather formal description receives its

35 Hirsch, Leitfaden zur christlichen Lehre, p. 132 (§ 73): „Christlichem Glauben ist die der Gottes- und Selbsterkenntnis des Menschen zum Schicksal werdende Begegnung mit dem Menschen Jesus der Ort dessen, das wir die letzte oder entscheidende Offenbarung genannt haben."

36 Hirsch, Leitfaden zur christlichen Lehre, p. 133 ( $§ 73$ ): „Gegenwärtigsein Gottes im Gewissen“.

37 Hirsch, Leitfaden zur christlichen Lehre, p. 133 (§ 73): „vertiefender und [...] verwandelnder Offenbarung".

38 Hirsch, Leitfaden zur christlichen Lehre, p. 133 (§ 73): „hellt mir das Gottesverhältnis auf, in dem ich schon bin“.

39 Hirsch, Leitfaden zur christlichen Lehre, p. 133 (§ 73): "gibt mir ein irgendwie gegensätzlich zu dem bisherigen bestimmtes Gottesverhältnis“. 
materialisation with regard to the meaning of Jesus as the undisputable centre of Christian faith. "Such content will be the distinction of law and gospel."40

Looking at Hirsch's understanding of Christianity in general, it is not exaggerated to identify the difference of law and gospel as its systematic key figure. Dogmatics as well as Christian ethics and hermeneutics of the New Testament were all essentially structured by means of the above-mentioned Lutheran concept which is explained within the framework of Hirsch's theory of a twofold divine revelation: "Revelation as law and as gospel". ${ }^{41}$ In accordance with the idea already expressed in Psalm 62 - Once God has spoken; twice have I heard this: that power belongs to God - the necessity of antithetic terms in order to express the relationship of finite and divine sphere comes to light. Even the self-revealing word of God appears ambivalent to human understanding due to our limited abilities. The lord is one but our understanding lacks his clearness and unity. "It is characteristic to a clearly self-understanding Christian faith, to be conscious of God's self-revealing as happening in antithetic doubleness." ${ }^{42}$

On the one hand, the human subject experiences itself within the natural context of life in all its finitude, which tends to press more or less hard on every human being as well as living beings in general. The vitalist tradition of philosophy of life from Nietzsche to Albert Schweitzer might play a role in those considerations. One just needs to be reminded of Schweitzer's formula of us existing as "beings that want to live among other beings who want to live" in order to illustrate the modern existential thinking which also dominates Hirsch's version of the Lutheran antithesis of law and gospel. ${ }^{43}$ Another strong source that has to be taken into account is the romantic-idealistic existentialism of the great philosopher, theologian and poet from Copenhagen. ${ }^{44}$ Kierkegaard's expression of humans' situation of "desperately not wanting to be oneself and desperately wanting to be oneself" 45 is not only the offspring of existentialism as we know it today. Beyond that, his ambition was to give a contemporary expression and translation for the precise meaning of the word

$40 \quad$ Hirsch, Leitfaden zur christlichen Lehre, p. 133 (§ 73): „Als solche inhaltliche Bestimmung wird sich uns die Unterscheindung von Gesetz und Evangelium erweisen."

41 Hirsch, Leitfaden zur christlichen Lehre, p. 134 (§ 74): „Offenbarung als Gesetz und als Evangelium".

42 Hirsch, Leitfaden zur christlichen Lehre, p. 134 et seq. (§ 74): „Es ist sich klar verstehendem christlichen Glauben eigentümlich, Gottes Sichoffenbaren als in antithetischer Zweigestalt geschehend gegenwärtig zu haben."

43 See Hirsch, Zur Grundlegung der Ethik.

44 Hirsch already had finished his volumes on Kierkegaard in 1933 before starting his impressive translation of the Danish's entire works after wwiI.

45 Kierkegaard, Die Krankheit zum Tode, p. 396/sv XI, p. 127: „verzweifelt nicht man selbst sein wollen; verzweifelt man selbst sein wollen“. 
to the Christian phenomenon of a consciousness of sin. The inescapable task to realize oneself as a self-confident human being and member of modern society with all its pressures marks the new version of the old wisdom that finitude not only means the possibility to fall but it also implies the undeniable human fate to willingly or unwillingly get entangled in guilt towards fellow creatures and therefore also towards the common divine creator. The function of the law within the notion of law and gospel aims at the religious reflection of that harsh matrix of human existence in light of the unconditional will of God. Encountering his demanding side produces the experience of existential pressure upon the religious subject which results from our finite character, preventing us from mishearing what God said once.

In the enigmatic and contradictory relationship to God that every human being experiences in his historical existence by living through it in conscience according to the law of life that governs him and the determination granted to him before God, Christian faith recognizes God's revelation of the law. ${ }^{46}$

On the other hand, the changing power of gospel picks up the religious individual from where it became entangled in sin and despair, which - according to Hirsch - led to the untrue picture of God as an angry opponent suppressing man's freedom by his merciless law. ${ }^{47}$ Whereas the enigmatic and frightening aspect of encountering the divine appears in the law, the loving and caring side of God's revelation is represented in the gospel of Jesus Christ. Christian faith

confronts it [the revelation of the law] with the certainty of God given to the conscience in the encounter with the man Jesus as the one who is the love that sustains my life and takes me for her child without any reason, as God's revelation of the gospel, which liberates man under the law from the law. ${ }^{48}$

46 Hirsch, Leitfaden zur christlichen Lehre, p. 135 (§ 74): „In der rätselhaften und widersprüchlichen Gottesbeziehung, die jeder Mensch in seinem geschichtlichen Dasein erfährt, indem er es nach dem darin an ihm waltenden Gesetz des Lebens und der darin ihm gewährten Bestimmung vor Gott im Gewissen durchlebt, erkennt christlicher Glaube Gottes Gesetzesoffenbarung."

47 See Hirsch, Leitfaden zur christlichen Lehre, p. 135 (\$ 74).

48 Hirsch, Leitfaden zur christlichen Lehre, p. 135 (§ 74): „Ihr [der Gesetzesoffenbarung] stellt er die dem Gewissen in der Begegnung mit dem Menschen Jesus sich schenkende Gewißheit Gottes als des, der die mir ewig das Leben tragende, mich zu ihrem Kinde grundlos nehmende Liebe ist, gegenüber als Gottes den Menschen unter dem Gesetz vom Gesetz freimachende Evangeliumsoffenbarung." 
The deepening side of revelation through the experience of the law of life, which recognizes the real circumstances of human existence, concluded in a false notion of the divine as unloving or suppressing its creature. Thereby truth had been turned into untruth with regard to the concept of God, under whose law the religious subject is living according to its own interpretation of life. "The light of the revelation of the gospel, however, reveals the revelation of the law according to its untruth and thus transforms conscience." ${ }^{49}$ Searching for the true encounter with the divine sphere within the obedience to religious rules and regulations or under the circumstances of natural life in general cannot reveal the true heart of God versus his creature. Instead, its wrong picture of him would imprison the religious conscience rather than liberate it from self-made bounds. An abstract notion of divine anger has to be converted into the concept of real recognition and love. This changing potential of revelation within the gospel cannot be realized but through interpersonal encounter. "Only when a human-historical reality opens up to us, which is free from it under this law as life in the love of God, which deprives the law of his divine power over man, does God speak to us as the gospel that changes conscience." 50

There is obviously a twofold concept of law present in this Lutheran notion of God's revelation in law and gospel. The truth of a law of life, which does represent all our finite relationships as well as conditions of human life, is recognized within the framework of this concept. Yet, all related conclusions regarding the nature of God are disclosed in their misleading and untrue manners. Thus, the antithetic idea of an existing law of life, which at the same time must not be extended to the religious sphere, is established in order to prepare the faithful conscience for encountering Jesus Christ in his gospel. This "sublation of law into gospel [...] honours the law of life itself as sacred, but [is] cutting it through as a truth laying trapped in untruth".51

49 Hirsch,LeitfadenzurchristlichenLehre, p.135(§ 74):„Das Licht derEvangeliumsoffenbarung aber enthüllt die Gesetzesoffenbarung nach dieser ihrer Unwahrheit und verwandelt damit das Gewissen."

50 Hirsch, Leitfaden zur christlichen Lehre, p. 136 (§ 74): „Nur indem sich uns eine menschlichgeschichtliche Wirklichkeit aufschließt, die unter diesem Gesetz stehend von ihm frei ist als Leben in der das Gesetz seiner Gottesmacht über den Menschen entsetzenden Liebe Gottes, spricht Gott zu uns als Evangelium, das das Gewissen verwandelt."

51 Hirsch, Leitfaden zur christlichen Lehre, p. 135 (§ 74): „Aufhebung des Gesetzes hinein ins Evangelium, die das Gesetz des Lebens selbst als heilig ehrt, das Gesetz als Gottesmacht aber durchscheidet [sic] als in Unwahrheit gefangen liegende Wahrheit“. 
Like his academic father figure Karl Holl, the systematic head of the LutherRenaissance Emanuel Hirsch also relates to the ethical side of Luther's works. ${ }^{52}$ Therefore, he engages with the institutional meaning of law which aims at the realm of right and public affairs rather than the religious sphere of faith. First of all, Hirsch distinguishes a double use of law in Luther's thought, "the 'civil' and the 'sacred' use of law"53 reflecting the important difference between the two essential fields of human life: being a (Christian) human being among humans and being human before God. Of course, all matters of moral and ethical significance belong to the sphere of civil law, whereas the religious meaning of law is restricted to the above explained function towards the gospel in Jesus Christ. "The 'civil' usage leads to what is called here the law of life which determines human coexistence and is powerful in historical reality." ${ }^{54}$ Significantly, the place of phenomenological appearance of that civil aspect of law is not society in general, as one might expect, but the already structured sphere of social life as given in certain historic forms of human community. That is why Hirsch deals with the ethical side of law in the context of his theory of human order. The term "society" does not play a major role in his considerations, which might be due to its usage in socialist circles of the time before the end of wwII. Instead, the notion of state in conjunction with the idea of the people as "Volk" has the central position in Hirsch's assessment of the ethical meaning of civil law. As mentioned above, the public sphere is considered the practical field of certain historic forms and rules grown within the boundaries of culture, which also imply rather vague and unexplained ethnic distinctions. ${ }^{55}$ "The state is order and the power of order in an inseparable unity, i.e., the order that encompasses and determines all other order in historical community, the power of order to which all other powers of order are classified and subject."56 This almost metaphysical understanding of the state's reach and might is quite characteristic to Lutheran ethics between the world wars. And it is not

$5^{2}$ See Lobe, Die Prinzipien der Ethik Emanuel Hirschs, pp. 56-67.

53 Hirsch, Leitfaden zur christlichen Lehre, p. 137 (\$ 74. M 2): „Luther hat einen zwiefachen Brauch des Gesetzes unterschieden, den ,bürgerlichen' und den ,heiligen'“.

54 Hirsch, Leitfaden zur christlichen Lehre, p. 137 (§ 74): „Der ,bürgerliche“ Brauch führt auf das, was hier das das menschliche Miteinandersein bestimmende, an der geschichtlichen Wirklichkeit mächtige Gesetz des Lebens genannt ist“. Hirsch obviously applied his ethics to Nazi-Racism.

56 Hirsch, Leitfaden zur christlichen Lehre, p. 243 (§ 116): „Der Staat ist Ordnung und Ordnungsmacht in untrennlicher Einheit, d.h. also die Ordnung, die alle andre Ordnung in geschichtlicher Gemeinschaft ordnend umfaßt und bestimmt, die Ordnungsmacht, der alle andern Ordnungsmächte eingeordnet und unterworfen sind.“ 
surprising that conservative as well as nationalist theologians applied that strong position of the state to their own thought in order to sublime their - at least imagined - suppression by the terms of the Versailles Treaty. Moreover, the tight conjunction of state and people that appeared in Hegel's Elements of the Philosophy of Right (1821) comes to the surface again in Hirsch's Neo-Lutheran ethics: "The state is the nation legally united as an independent power. Taken in this way, it is both a requirement and a task for all ethical action". ${ }^{57}$

But this conjunction of nation and law immediately leads Hirsch towards the sharp contrast of the (European) nations - in plural - and their political traditions which eventually result in contradicting forms of statehood. "The main theme of the peoples' own eventful history is the right formation and development of their statehood." ${ }^{58}$ And in the nationalist tradition of the summer of 1914 (which paved the way to January 1933), the different histories of statehood come to light as antagonist examples of ideas fighting each other. Being a rather typical representative of German Lutheran intellectuals on the nationalist end of the political spectrum, Hirsch exposes the opposing understandings of the relationship between state and law as the main difference that finds its battleground on the (ideological) fields of history. "Our current Western thinking is divided by the numerous political upheavals of the last centuries over the question of the relationship between state and law."59 Coming from a strong knowledge of Luther and classical German philosophy especially the wwI nationalist reading of Fichte's philosophy of right - the presupposed originality of a certain understanding of that relationship rules Hirsch's reconstruction of the matter. ${ }^{60}$

On the one hand, the philosophical tradition deriving from the thought of people like Jean Jacques Rousseau is introduced as the source of Western

57 Hirsch, Leitfaden zur christlichen Lehre, p. 244 (§ 116): ,[D]er Staat ist das als unabhängige Macht rechtlich geeinte Volk. So genommen ist er zugleich Voraussetzung wie Aufgabe für alles ethische Handeln“. See Holzbauer, Nation und Identität, pp. 69-171, on Hirsch's political theology with regard to the German state after 1918 and his concept of nation which was profoundly shaped by wwI, although he did not serve in the war himself due to his poor health.

$5^{8}$ Hirsch, Leitfaden zur christlichen Lehre, p. 244 (§ 116): „Die Völker haben an der rechten Gestaltung und Entfaltung ihrer Staatlichkeit das Hauptthema ihrer eignen bewegten Geschichte."

59 Hirsch, Leitfaden zur christlichen Lehre, p. 245 (§ 116): „Unser gegenwärtiges abendländisches Denken ist durch die zahlreichen politischen Umbrüche der letzten Jahrhunderte in sich entzweit über die Frage nach dem Verhältnis von Staat und Recht.“

6o See Hirsch, Christliche Rechenschaft, pp. 276-277. Regarding Fichte's general impact on the Lutheran ethics of Emanuel Hirsch see Lobe, Die Prinzipien der Ethik Emanuel Hirschs, pp. 11-37. 
democracy, not mentioning the liberal tradition of John Locke at all. Here, the balance between state and law is clearly in favour of the latter. Insofar as the law applies to the state and its institutions themselves, the individual's right to freedom is upheld. The state itself only functions as a means to an end, which is the enforcement und security of individual and God given rights.

The Western view understands the state as a tool of the law that is above it, which to a certain extent limits it in its exercise of power over the individual; it believes that there is personal freedom and self-determination only in a constitutional state of this kind. ${ }^{61}$

As a result of a secular derivate of the Old Testament's concept of an ethical law given by the almighty God to his people, the notion of the state was limited in its power. According to the primordial position of the ethical or moral law Hirsch is thinking in Kantian terms - which expresses itself in legal rights, the state has to recognize its own subordinate status. "The Western view is based on the idea that the state, as an exercise of power, is only ethical if it subordinates itself as a servant to the moral law, which is to a certain extent expressed in the law."62

On the other hand, the German understanding of statehood and law in the tradition of Luther, Fichte (and Hegel) is exposed as the opposite relationship of both elements. In his personal annotations, Hirsch refers to Fichte's Closed Commercial State (180o), Characteristics of the Present Age (1806) and the Addresses to the German Nation (1808). ${ }^{63}$ The state is under no circumstances the subordinate servant of natural law, neither is it the tool of God-given human rights which find their legal expression in the particular laws of a country. On the contrary, the state as the living will of the nation becomes the source of all legal distinctions.

The German view of today understands the state strictly as the one who sets the law, the one who rules and decides on common life through the

61 Hirsch, Leitfaden zur christlichen Lehre, p. 245 (§ 116): „Die westliche Anschauung versteht den Staat als Werkzeug des über ihm stehenden Rechts, das ihn gewissermaßen in seiner Machtübung dem Einzelnen gegenüber begrenzt; sie meint nur in einem Rechtstaate dieser Art gebe es persönliche Freiheit und Selbstbestimmung."

62 Hirsch, Leitfaden zur christlichen Lehre, p. 245 (§ 116): „Der westlichen Anschauung liegt die Vorstellung zugrunde, daß der Staat als Machtausübung nur dann ethisch sei, wenn er sich dem Sittengesetze, das sich im Recht gewissermaßen ausspricht, als Diener unterordne."

63 See Hirsch, Christliche Rechenschaft, p. 276. 
law as its instrument; it believes that only in a legal state of this kind can the political community be the full realization of salvation and peace and grant everyone a personal existence in honor and according to their destiny. ${ }^{64}$

Instead of a natural or divine moral which functions as his law ruling the state, the latter one gains the primordial position representing the divine idea of order in general. Thus, the state shall create the positive law imposing its order on the living community of man.

According to the only human true understanding that has been assigned to us by the Christian religion, God is, in contrast, related to our common life as the living being who, through the mystery of our originality, which springs from the forces of life, opens up being for one another in the reciprocity of giving and receiving, and the State is God's order because it is placed above it as guardian and custodian. ${ }^{65}$

In other words, the difference of understanding statehood and law was reflecting the divergent philosophical traditions and the difference between Christian and Jewish. Here, the Lutheran intellectual Hirsch reveals himself to be an obedient servant to the ideology of the NSDAP he joined in 1937, when many of his contemporaries had already left it. ${ }^{66}$ Yet, his views significantly reflect the wide-spread nationalist side of Lutheran thought on the notion of political and religious law prior to $1945 \cdot{ }^{67}$

64 Hirsch, Leitfaden zur christlichen Lehre, p. 245 (§ 116): „Die heutige deutsche Anschauung versteht den Staat streng als den das Recht Setzenden, den durch das Recht als sein Werkzeug herrschend und verfügend am gemeinsamen Leben Waltenden; sie meint, nur in einem Rechtsstaat solcher Art könne die politische Gemeinschaft ganze Verwirklichung des Heils und Friedens sein und jedem ein persönliches Dasein in Ehre und nach der Bestimmung gewähren."

65 Hirsch, Leitfaden zur christlichen Lehre, pp. 245-246 (§ 116): „Nach dem von der christlichen Religion her uns gewordnen, allein menschlich wahren Verständnis dagegen ist Gott auf unser gemeinsames Leben bezogen als der Lebendige, der uns durch das Geheimnis unsrer aus den Lebensmächten quellenden Ursprünglichkeit dem Sein füreinander in der Wechselseitigkeit des Gebens und Empfangens aufschließt, und der Staat ist deshalb Gottes Ordnung, weil er darüber als Hüter und Walter gesetzt ist.“

66 See Schütte, Christliche Rechenschaft und Gegenwartsdeutung.

67 See Tanner, Die fromme Verstaatlichung des Gewissens. 
The catastrophe of WWII and the atrocities committed by the Nazi Regime especially the Shoah - shed a new light upon the entanglement of Lutheran Church and theology in those crimes and the ideology behind them. The close bond to the authoritarian concept of nationalism as reflected in Lutheran concepts e.g., the theory of the two realms - religious and public sphere - and the strong impact of the notion of order in this context came under serious revision in the 1950s. ${ }^{68}$

Among the academic Lutheran theologians of the time, Wolfgang Trillhaas (1903-1995) stands out not only for being a pre-war student of both Karl Barth (1886-1968) - the reformed theologian who had famously reversed the formula of law and gospel into "gospel and law"69 - and his Lutheran opponent Emanuel Hirsch, ${ }^{70}$ but also for his books on Protestant dogmatics and ethics, which have been most influential for study ever since the 196os. Therefore, a closer look at his different approach to the concept of law in its double character shall also shed a light on the general development after wWII.

His notion of the religious dimension of law starts from the clear distinction of a natural legal context - the sphere described as the law of life or sin - from its meaning under Christian conditions. "It is under the sign of the gospel, yes it should be understood entirely as the gospel." ${ }^{\prime 1}$ Instead of restricting the law to the sphere of the natural human being in opposition to the new creature in Christ, he reflects on its affirmative role for Christian faith. Thus, Trillhaas leaves the classical Lutheran idea of the universal hermeneutical concept of "law and gospel" behind in order to gain a positive understanding of law. "Law and gospel are more to us [...] than bearers of a dialectic in the word of God".72 This changed perspective is based on the concept of law's preserving power for the benefit of the faithful Christian. Other than the strictly negative function of the usus theologicus or usus elenchticus legis as revealing human sin, this affirmative dimension of a religious notion of the law overcomes the previous Lutheran restrictions. "In any case, it will no longer be possible to overlook the extent to which the law is also a messenger of God's gracious will to

\footnotetext{
68 See Scherf, Gesetz und Evangelium im Nachkriegsprotestantismus.

69 See Barth, Evangelium und Gesetz.

70 See Dahlgrün, Trillhaas, Wolfgang (1903-1995). See also his autobiography: Trillhaas, Aufgehobene Vergangenheit.

71 Trillhaas, Dogmatik, p. 234: „Es steht unter dem Vorzeichen des Evangeliums, ja es soll ganz als Evangelium verstanden werden."

72 Trillhaas, Dogmatik, p. 234: „Gesetz und Evangelium sind uns [...] mehr als die Träger einer Dialektik im Worte Gottes“.
} 
receive what he has created. The law is a force that keeps people from falling into the abyss." ${ }^{73}$ Yet, the connection with the fragile sphere of the finite and sin still remains in his new perspective insofar as the preserving function is in itself limited to keeping a systematic status quo. "It is a preserving power, nothing more." ${ }^{74}$ Nothing positive is accomplished by the religious law in the sense that God's revelation must not be restricted to legal terms. Otherwise, the depth and truth of the gospel as faith in Jesus Christ would be bound again. The negative focus of law in Lutheran thought is diminished, but at the same time its revealing function stays within the limits of the finite status of the human individual. "Ethics and religion, understood as law, surround man in his old being and in his frailty. They remind him of his humanity, they show him his limits and they accuse him." ${ }^{75}$ And so the changed perspective on the religious concept of law combines the specific Lutheran features with the lesson that divine law, as laid down in the biblical writings, has its own religious significance. The previous neglection of the affirmative aspect of law in favour of the notion of gospel gives way to a smooth appreciation of both. Eventually, Trillhaas - himself an open-minded Lutheran from southern Germany with its more colourful Protestantism in terms of liturgical traditions etc. - sums up four main points regarding his view on the concept of "law and gospel" keeping a slightly modernized version of the Lutheran original:

1. The law is brought up before the gospel. [...] 2. A strict distinction must be made between law and gospel. What is new, of which we shall now speak in the following, must not be passed on as law again. [...] 3. Even for Christians who have accepted the gospel and who live under the gospel, the meaning of the law continues; for Christians too need the sustaining grace of God for their temporal life. 4. There is no parallel between the law and the gospel. Rather, the gospel far outweighs the law. It outweighs the law so much that even the law can be understood in the light of the gospel. ${ }^{76}$

73 Trillhaas, Dogmatik, p. 234: „Es wird jedenfalls nicht mehr übersehen werden können, inwiefern auch das Gesetz ein Bote des gnädigen Willens Gottes ist, was er geschaffen hat, auch zu erhalten. Das Gesetz ist eine Ordnungsmacht, die den Menschen vor dem Fall ins Bodenlose bewahrt."

74 Trillhaas, Dogmatik, p. 234: „Es ist eine bewahrende Macht, mehr nicht.“

75 Trillhaas, Dogmatik, p. 234: „Ethik und Religion, als Gesetz verstanden, umgeben den Menschen in seinem alten Sein und in seiner Hinfälligkeit. Sie erinnern ihn an sein Menschsein, sie zeigen ihm seine Schranken und sie klagen ihn an.“

76 Trillhaas, Dogmatik, pp. 234-235: „1. Das Gesetz wird vor dem Evangelium zur Sprache gebracht. [...] 2. Gesetz und Evangelium sind streng zu unterscheiden. Das Neue, von dem nun im folgenden die Rede sein soll, darf nicht wieder als Gesetz ausgegeben 
While numbers one and two are in keeping with the pre-war Lutheran tradition, three and four clearly reflect a reformed or Presbyterian influence - very likely by Karl Barth's theology - which brings the affirmative side of law to the table again. Thus, the core of Lutheran reflection on the religious dimension of law experienced a slight but profound change in the aftermath of WwII in gaining a positive function which transcends the previous restriction to exposure of sin and paves the way towards (slowly enough) overcoming anti-Jewish stereotypes in Lutheran theology. God's law preserves the natural human being as well as the faithful Christian. And that is what eventually reveals the true significance of the gospel.

Besides his considerations on "law and gospel", Trillhaas also engages with the ethical aspect of law in Lutheran theology. In his ethics he gives his own reception of the Lutheran doctrine of state and law, again with remarkable changes that reflect the different situation under democratic conditions in the Federal Republic of Germany after 1949. As a main premise, Trillhaas recognizes the deficit of an actual doctrine of state in Luther's and Lutheran ethics. "What lives in the theological tradition as the Lutheran doctrine of the state is essentially a doctrine of the authorities or worldly power."77 Therefore, the problem of its adequacy in modern democratic society arises. The previous model of hierarchy as conveyed by Lutheran thought is based on the concept of the hidden government of the divine by means of the secular authorities, which the individual simply has to obey. "The government is from God, and there is no government that is not from God."78 In the light of the fatal consequences of the totalitarian regime in Germany, Trillhaas clearly points out the deficiency of that traditional concept of government. Instead of undertaking another attempt to explain modern statehood in terms of authorities and subjects, he affirms the democratic structures established in the post-war society.

The modern state problem can no longer be grasped with the relationship between superiors and subjects. [...] Rather, modern state thought

werden. [...] 3. Auch für die Christen, die das Evangelium angenommen haben und die unter dem Evangelium leben, dauert das Gesetz in seiner Bedeutung fort; denn auch die Christen bedürfen der erhaltenden Gnade Gottes für ihr zeitliches Leben. 4. Es besteht keine Parallele zwischen Gesetz und Evangelium. Vielmehr überwiegt das Evangelium das Gesetz weit. Es überwiegt das Gesetz so weit, daß sogar das Gesetz im Lichte des Evangeliums verstanden werden kann.“

77 Trillhaas, Ethik, p. 370: „Was in der theologischen Tradition als lutherische Staatslehre lebt, ist im wesentlichen eine Lehre von der Obrigkeit bzw. von der weltlichen Gewalt."

78 Trillhaas, Ethik, p. 371: „Die Obrigkeit ist von Gott, und es ist keine Obrigkeit, die nicht von Gott wäre.“ 
begins at the moment when 'the state' confronts both the subject - if you will - and the 'superiors' as a third party. ${ }^{79}$

As an important result of this changed structure of modern theory of state derives the democratic idea of participation as the necessary condition for the individual's recognition from the public sphere and its institutions. "As soon as one sees only an obedience problem here, the citizen of this system has already become alien to the system itself" ${ }^{80}$ Finally, the modern importance of democratic structures and constitution prefigures the form in which also Christian ethics has to approach the notion of state and law. Analysing the undeniable political and religious changes in the 2oth century, Trillhaas comes to the conclusion that there is no way to maintain the traditional Lutheran ethical point of view. And thus, he bids farewell to the doctrine of the two realms and the pre-democratic construction of state: "A construction of the state from the unseen conditions of the sixteenth century simply bypasses the reality of the present-day state. ${ }^{\prime 1}$

This paradigmatic change regarding the idea of the modern secular state must also affect the Lutheran concept of law. ${ }^{82}$ Unlike his Lutheran teacher Hirsch, the notions of state and law are no longer exposed utilizing the opposition of Western and German ideas. The stubborn neglection of the mere possibility of a systematic superiority of right or law above the metaphysical notion of the state gives way to a much more flexible understanding. All finite institutions - religious and secular ones - have to recognize the global validity of the legal right's sphere.

We speak of the 'sovereignty' or even 'holiness' of the law and mean by this that the law does not originally stand in the servitude of an earthly authority - be it the state, church or an international organization - but that it is ideally related to justice itself. [...] All laws must be aligned with

79 Trillhaas, Ethik, p. 373: „Das moderne Staatsproblem ist mit dem Verhältnis von Oberpersonen und Untertanen nicht mehr zu fassen. [...] Das moderne Staatsdenken beginnt vielmehr in dem Augenblick, wo ,der Staat' sowohl dem Untertanen - wenn man so will - als auch den ,Oberpersonen' als ein Drittes gegenübertritt.“

8o Trillhaas, Ethik, p. 374: „Sobald man hier nur ein Gehorsamsproblem sieht, ist der Bürger dieses Systems dem System selbst schon fremd geworden“.

81 Trillhaas, Ethik, p. 375: „eine Konstruktion des Staates aus den unbesehenen Voraussetzungen des 16. Jahrhunderts geht an der Wirklichkeit des heutigen Staates einfach vorbei.“

82 See Trillhaas, Ethik, p. 378 with regard to the secular character of the democratic state: "Der christlich verstandene Staat ist der 'weltliche' Staat. [The Christian state is the 'secular' state.]" 
the idea of law. As an independent order, the law is superior to all community orders and their needs. ${ }^{83}$

Looking back at Trillhaas' transformation of the anti-democratic conception of law in the 1920 and 30 s as well as his significant alterations to the classical religious distinction of law and gospel, we are obviously facing two major achievements. First, the conservative idea of the metaphysically based state which defines and imposes the law has been de-potentialized. And the notion of a reversed order of law and state has been established. Second, the limited function of the religious law which resulted in a pejorative understanding has also been de-potentialized, thus not only recognizing an affirmative potential of the law but also emphasizing the true impact and reach of the gospel itself.

Hardly any theological concept has undergone such a dramatic transformation in Lutheran Protestantism in the course of the 2oth century as the discourse on the law. Before 1945, the religious meaning of the law - following Martin Luther - was limited primarily to its negative, convicting role in the anthropological context of the Christian knowledge of sin. As a result, only the legal concept in the sense of the state community and one's own nation remained as a positive point of reference. Representatives of the theological New Idealism, such as Emanuel Hirsch, combined Lutheran thinking about the authorities and the state with an increasingly nationalistic interpretation of Fichte's practical philosophy. This melange resulted in a concept of law that was very tense in itself and whose two correlates, the knowledge of sin and the theory of the state, could be elaborated at the highest intellectual level. The dialectic of the Christian conscience and the regulatory function of the state community were pursued down to the smallest ramifications. However, from a political point of view, this path did not lead to Lutheran freedom from the law, but to its sell-out to the totalitarian and nationalist state. The fact that Lutheran theology thought it could refer to the Reformer himself and his philosophical

83 Trillhaas, Ethik, p. 382: „Wir sprechen von der ,Hoheit‘ oder gar ,Heiligkeit‘ des Rechtes und meinen damit, daß das Recht ursprünglich nicht in der Dienstbarkeit einer irdischen Autorität - sei es Staat, Kirche oder eine internationale Organisation - steht, sondern daß es ideal auf die Gerechtigkeit selbst bezogen ist. [...] Alle Gesetze müssen an der Idee des Rechtes ausgerichtet werden. Das Recht ist als selbständige Ordnung allen Gemeinschaftsordnungen und deren Bedürfnissen überlegen.“ 
heirs in German idealism certainly contributed to the strong dynamics of this development.

It was not until the catastrophe of the Second World War and the liberation from the Nazi regime that external circumstances made a fundamental redefinition of the concept of law necessary. On the one hand, this included the affirmative reference to the divine law as an essential component of the gospel itself, the theological recognition of a positive function of the law in the religious sphere, thus breaking down the rigid scheme of law and gospel. On the other hand, Lutheranism reacted to the newly established democratic social order, which had also replaced the totalitarian state. This meant that all the authoritarian-conservative state theories of Lutheran social ethics from the pre-war period had become obsolete. Instead, it was necessary to develop and theologically justify an affirmative relationship to modern democracy with a positive conception of the law. The nation was replaced by the idea of law and the democratically legitimised constitutional state. One could hardly have asked Lutheran theology to go further with regard to the concept of law. From there, we look at Protestantism in the 21st century.

Contemporary Lutheran Protestantism - at least in Germany - is characterized by a deep ambivalence concerning the notion of law. On the one hand, Martin Luther's original rejection of any religious benefit of the law transcending its theological function to unveil man's sinful character in order to trigger a contrite heart still rules the religious and theological approach. At least a profound hesitance regarding all legal forms of religion, religious community or traditionalism is part of the heritage in the Lutheran Church. The central role of Christian faith as trust in God marks the strong positive side of that heritage, of course. Yet, a certain prejudice towards everything legal in the religious sphere dominated the Protestant relationship to other traditions such as the Catholic Church and Judaism, tendencies which for the most part have been overcome in contemporary theology.

On the other hand, the previously exclusive restriction of the legal concept to the public sphere of state which resulted in a Lutheran affirmation of authoritarian forms of statehood - be it monarchy, anti-democratic conservatism or plain nationalism paving the way for the Nazi-regime of 19331945 - has been overthrown not only by the dramatic change of the political conditions in history. Moreover, the adaption of the Presbyterian concept of the synodal system helped establish democratic structures in the Lutheran churches, too. Thus, the long way to an explicit affirmation of the democratic system in Protestantism in Germany, which eventually resulted in the memorandum on democracy published by the Evangelical Church in Germany in 1985, took off. Finally, the public role of the Protestant Church with its religious 
and ethical values in social discourses changed the attitude towards the idea of legal rights. The participation in the formation process of social developments in the context of democratic legislation raised the acceptance of the democratic state itself as well as the recognition of the religious and ethical value of law. The merit of having values of faith and morality is much more consciously prevalent among protestants today.

Therefore, the diagnosis of the contemporary Lutheran approach to the concept of law might conclude with an emphasis on the affirming aspects in its usage within the Lutheran Church as well as its increasing appreciation in theological thought from exegesis to dogmatics and ethics. Yet, the picture would be incomplete without mentioning conservatists' criticism of the ethical views of Protestant church officials regarding homosexual marriage, migration or the current nationalist tendencies in Germany, which do not necessarily stop at church doors.

So, the ambivalence of the meaning of law in Lutheran Protestantism continues to give further material for thought and theological discussion.

\section{Biography}

Born 1980; 2002-2009 studies of protestant theology in Halle a. d. Saale, Jerusalem, Göttingen and Neuendettelsau; 2010-2013 Vicar nearWürzburg; 2013 ordained pastor in the Lutheran Church in Bavaria; 2018 Doctor of Theology (ThD); since 2014 Lecturer in Systematic Theology at Augustana-Hochschule Neuendettelsau; selected publications: Luther verstehen. Person - Werk Wirkung, Leipzig 2016 (ed. with M. Buntfuß); Hegels Theorie des Erhabenen. Grenzgänge zwischen Theologie und philosophischer Ästhetik (BHTh 192) Tübingen 2019; fields of research: Lutheran Theology, German Idealism (Hegel), Aesthetics, Protestant Ethics of Law.

\section{Bibliography}

Assel, Heinrich: Der andere Aufbruch. Die Lutherrenaissance - Ursprünge, Aporien und Wege: Karl Holl, Emanuel Hirsch, Rudolf Hermann (1910-1935). Göttingen: Vandenhoeck \& Ruprecht 1994.

Assel, Heinrich: Introduction. Luther Renaissance and Dialectical Theology - A tour d'horizon 19o6-1935, in: Heinrich Assel/Bruce L. McCormack (eds.): Luther, Barth, and Movements of Theological Renewal (1918-1933). Berlin/Boston: DeGruyter 2020, pp. 1-16. 
Barniske, Friedemann: Persönlichkeitsreligion. Friedrich Brunstäds (neu)idealistische Lutherdeutung, in: Markus Buntfuß/Friedemann Barniske (eds.): Luther verstehen. Person - Werk - Wirkung. Leipzig: Evangelische Verlagsanstalt 2016, pp. 213-233.

Barth, Karl: Evangelium und Gesetz, in: Theologische Existenz heute 32 (1935). München: Kaiser.

Barth, Ulrich: Die Dialektik des Offenbarungsgedankens. Luthers Theologia crucis, in: Ulrich Barth (ed.): Aufgeklärter Protestantismus. Tübingen: Mohr Siebeck 2004, pp. 97-123.

Barth, Ulrich: Nachwort des Herausgebers. E. Hirschs Deutung der Religionsphilosophie Fichtes, in: Emanuel Hirsch: Fichte-Studien 1914-1929. Waltrop: Hartmut Spenner 2008, pp. 431-451.

Dahlgrün, Corinna: Trillhaas, Wolfgang (1903-1995), in: Theologische Realenzyklopädie 34 (2002), pp. 89-91.

Hirsch, Emanuel: Die Beisetzung der Romantiker in Hegels Phänomenologie. Ein Kommentar zu dem Abschnitte über die Moralität, in: Hans Friedrich Fulda/Dieter Henrich (eds.): Materialien zu Hegels ,Phänomenologie des Geistes'. Frankfurt am Main: Suhrkamp 1973, pp. 245-275.

Hirsch, Emanuel: Zur Grundlegung der Ethik. Eine Auseinandersetzung mit Albert Schweitzer, in: Die Tat 16 (4/1929), pp. 249-26o.

Hirsch, Emanuel: Leitfaden zur christlichen Lehre. Tübingen: Mohr Siebeck 1938.

Hirsch, Emanuel: Christliche Rechenschaft. Band 2. Bearbeitet von Hayo Gerdes. Neuausgabe besorgt von Hans Hirsch. Tübingen: Katzmann 1989.

Holl, Karl: Gesammelte Aufsätze zur Kirchengeschichte. Band 1, Luther. Tübingen: Mohr Siebeck 1921.

Holzbauer, Andreas: Nation und Identität. Die politischen Theologien von Emanuel Hirsch, Friedrich Gogarten und Werner Elert aus postmoderner Perspektive. Tübingen: Mohr Siebeck 2012.

Kierkegaard, Søren: Die Krankheit zum Tode, in: Søren Kierkegaard (ed.): Werkausgabe Band 1. Übers. von Emanuel Hirsch. Düsseldorf/Köln: Eugen Diederichs 1971, pp. 389-551/Samlede Vaerker Bd. XI (1905), pp. 111-28o.

Lobe, Matthias: Die Prinzipien der Ethik Emanuel Hirschs. Berlin/New York: DeGruyter 1996.

Luther, Martin: Luthers Werke, Kritische Gesamtausgabe, 57 vols. Eds. J.F.K. Knaake et al. Weimar: Böhlau, 1883 ff. [= WA] .

Luther, Martin: Heidelberg Disputation, 1518. Translated by Harold J. Grimm, in:Luther's Works. American Edition, Vol 31. Career of the Reformer: I. Edited by HaroldJ. Grimm. Philadelphia: Fortress Press ${ }^{4} 1979$, pp. 35-70.

Luther, Martin: Disputatio Heidelbergae habita/Heidelberger Disputation (1518), in: Wilfried Härle (ed.): Martin Luther. Lateinisch-Deutsche Studienausgabe. Band I. 
Der Mensch vor Gott, Leipzig: Evangelische Verlagsanstalt ${ }^{2} 2016$, pp. 35-69/WA 1, pp. $355^{-365}$.

Scherf, David: Gesetz und Evangelium im Nachkriegsprotestantismus. Religion in der Bundesrepublik Deutschland. Band 5. Tübingen: Mohr Siebeck 2019.

Schütte, Hans-Walter: Christliche Rechenschaft und Gegenwartsdeutung. Zum theologischen Werk E. Hirschs, in: Joachim Ringleben (ed.): Christentumsgeschichte und Wahrheitsbewußtsein. Studien zur Theologie Emanuel Hirschs, Berlin/New York: DeGruyter 1991, pp. 1-14.

Sohm, Rudolph: Kirchenrecht. Band I. München: Duncker \& Humblot 1970 [1892].

Tanner, Klaus: Die fromme Verstaatlichung des Gewissens. Zur Auseinandersetzung um die Legitimität der Weimarer Reichsverfassung in Staatsrechtswissenschaft und Theologie der zwanziger Jahre. Göttingen: Vandenhoeck \& Ruprecht 1989.

Thier, Andreas: Rudolph Sohm, in: Neue Deutsche Biographie (ND B) 24. Berlin: Duncker \& Humblot 2010, pp. 539-541.

Trillhaas, Wolfgang: Ethik. Berlin: Alfred Töpelmann ${ }^{2} 1965$.

Trillhaas, Wolfgang: Aufgehobene Vergangenheit. Aus meinem Leben. Göttingen: Vandenhoeck \& Ruprecht 1976.

Trillhaas, Wolfgang: Dogmatik. Berlin/New York: DeGruyter ${ }^{4} 1980$. 